\title{
Die metodiek en aanwendingsmoontlikhede van 'n markprysbepalingsmetode by onduursame verbruikersgoedere ${ }^{1}$
}

\author{
Chris P. Lerm \\ Departement Bedryfsekonomie, Randse Afrikaanse Universiteit, Johannesburg
}

\begin{abstract}
The methodology and applicability of a method to determine the market price of non-durable consumer products. Proper pricing should be done in three phases. Firstly, the determina. tion of the market price, namely that price which the consumers are prepared to pay for the amount of need-satisfaction they perceive from using the product. Secondly, the deter. mination of the target price, namely that price which will give a satisfactory rate of return on investment for the firm. Thirdly, the determination of the final price, by achieving a match between the market price and the target price. The present methods to determine the market price were analysed and with this information a new method to determine the market price of non-durable consumer products was developed. The objectives of this article are to report on an empirical investigation undertaken to test the feasibility of this method and the seven steps to follow in using the method; and to outline the results obtained and conclusions which may be reached; the implications and use of the empirical data; and the method to determine the market price.

S. Atr. J. Bus. Mgmt. 1982, 13: $28-37$
\end{abstract}

Behoorlike prysbepaling behoort in drie fases te geskied. Eerstens, die berekening van die markprys, naamlik die prys wat die verbruikers bereid is om te betaal vir die behoeftebevrediging wat die produk volgens hulle persepsie bied.

Tweedens, die bepaling van die doelwitprys, naamlik die prys wat aan die onderneming ' $n$ bevredigende rentabiliteit sal lewer en derdens die bepaling van die finale prys, deur middel van 'n versoening van die markprys en die doelwitprys. Uit die kennis wat ingesamel is tydens ' $n$ ondersoek na die huidige tegnologie rakende markprysbepaling, word 'n nuwe metode voorgestel om die markpryse van onduursame verbruikersgoedere te bepaal. Die doelstellings van hierdie artikel is om 'n uiteensetting te gee van 'n empiriese ondersoek wat uitgevoer is om die toepasbaarheid van hierdie metode te ondersoek en die sewe stappe wat gevolg is in die uitvoering van die metode; asook die resultate en gevolgtrekkings wat gemaak kan word; die implikasies en gebruik van die navorsingsresultate en die markprysbepalingsmetode.

S.-Afr. Tydskr. Bedryfsl. 1982, 13: $28-37$

\section{Die doel en onderliggende teorie van markprysbe. paling}

Markprysbepaling is ' $n$ moderne benadering waardeur daar gepoog word om beter prysbepalingsresultate te lewer as die tradisionele vraag-en-aanbodanalise, wat met behulp van die vraagkromme en die aanbodkromme poog om uitsluitsel te gee oor die vrae van hoeveel produkte teen welke prys verkoop kan word. ${ }^{2}$

In plaas van die tradisionele koste-georiënteerde benaderings kan bemarkingsbestuur deur middel van markprysbepaling werklike verbruikersgeoriënteerde prysbepaling toepas in lyn met die verbruikersgeorënteerde wesenskenmerk van die bemarkingskonsep. Die bemarker bepaal dus watter prys die verbruiker vir die produk wil betaal en hoeveel produkte hy gaan koop. Markprysbepaling kan dus deur bestuur gebruik word om meer sinvolle prysbeslissings te neem deur die markprys met die doelwitprys te vergelyk, ten einde 'n finale prys vas te stel.

Die markprys van 'n produk is daardie prys wat die verbruiker bereid is om te betaal vir die behoeftebevrediging wat die produk hom bied. Soos die benaming 'markprys' aandui, is dit die prys wat die mark via die verbruikers aan die onderneming beskikbaar stel en is dit die taak van die bemarkingsbestuur om hierdie prys waar te neem. Die markprys is dus basies daardie prys wat die bemarkingsbestuur bepaal deur van verbruikers hulle persepsie van die pryswaarde van die totale behoeftebevrediging van die produk te verkry.

Die verbruiker se bereidwilligheid om teen 'n bepaalde prys te koop word deur sy eie waarde-oordeel gevorm. Twee waardebegrippe word onderskei, naamlik die opbrengswaarde en die vervangingswaarde van die verbruiker. Die verbruiker baseer sy aankoopbesluit op die totale waarde wat hy waarneem, synde die som van die opbrengswaarde en die vervangingswaarde.

Die opbrengswaarde van die verbruiker spruit uit die opbrengs, of nut, of behoeftebevrediging wat die verbruiker verkry as gevolg van die besit, gebruik en beskikkingsmag oor die produk. Die opbrengswaarde of potensiële behoeftebevrediging volgens die verbruiker se persepsie, is die resultaat van die produk (resultaat van die bemarkingsbestuur se produkbeleid); die plek en gerief waarmee die aankoop gedoen kan word (resultaat van die bemarkingsbestuur se distribusiebeleid); kennis wat die verbruiker van die produk en die aankoopplek het 
(enersyds die resultaat van die bemarkingsbestuur se bemarkingskommunikasiebeleid en andersyds van die verbruiker se eie ondersoek en ondervinding); en die prys van die produk (resultaat van die bemarkingsbestuur se prysbeleid).

Die vervangingswaarde van die verbruiker bestaan weer uit sy persepsie van die opoffering wat hy moet maak om die opbrengswaarde te ontvang te wyte aan die prys wat hy moet betaal, plus die moeite, tyd en koste wat hy moet aangaan om die transaksie te sluit, byvoorbeeld reistyd en vervoerkoste na die winkel en die identifisering van die produk by die aankooppunt. Laasgenoemde staan dan ook bekend as verkrygingskoste.

Hieruit kan afgelei word dat die totale waarde via die opbrengs- en vervangingswaarde beinvloed word deur die geïntegreerde beleidsinstrumente of bemarkingsbeleid en -strategie van die onderneming, volgens die siening van die verbruiker, onderhewig aan sy gedrag as verbruiker.

Drie belangrike aspekte is onderliggend tot die basiese filosofie van markprysbepaling. Eerstens vorm die verbruiker 'n prys vir die produk deur 'n komplekse proses waardeur die prys opgeweeg word teen sy persepsie van voordele, koste, risiko en die gebruikswaarde van die produk. ${ }^{3}$ Hierdie proses is dus niks anders nie as die opweeg van die opbrengswaarde van 'n produk teen die vervangingswaarde volgens die persepsie van die verbruiker. 'n Tweede belangrike aspek is dat die verbruiker nie slegs een prys vir 'n produk sal betaal nie, maar bereid sal wees om ' $n$ hele aantal pryse vir die produk te betaal. Verbruikers sien dus die prys van die produk as 'n prysband bestaande uit 'n reeks van pryse. Hierdie prysband het twee limiete, naamlik 'n lae-prys limiet waaronder kwaliteit onder verdenking sal kom, en 'n hoë-prys limiet waar die vervangingswaarde hoër word as die opbrengswaarde wat die produk volgens die persepsie van die verbruiker bied. Die derde aspek behels die bepaling van die markprys, naamlik die prys binne die prysband wat vir die doelmark-verbruikers die aanvaarbaarste is.

\section{Die voorgestelde markprysbepalingsmetode}

In 'n ondersoek na die bestaande metodes om die markprys te bepaal, is elkeen afsonderlik ontleed met verwysing na die prosedure wat gebruik is en die sterk en swak punte van die metode. ${ }^{4}$ Met hierdie inligting as agtergrond kon 'n keuse gemaak word van die beste markprysbepalingsmetode wat ondersoek is ${ }^{5}$ en die metode aangepas word ten einde die geïdentifiseerde gebreke uit te skakel.

Eerstens is vier faktore onderskei wat 'n beperkende invloed sal uitoefen op die toepassing van die markprysresultate, naamlik prysbinding, prysbeheer, bemarkingskemas en produksiekapasiteit. Tweedens is twee besondere probleme in die toepassing van markprysbepalingsmetodes geidentifiseer, te wete die nuutheid van die produk en die invloed van mededingers se bemarkingsbeleid. Derdens is spesifieke vereistes geidentifiseer waaraan 'n goeie markprysbepalingsmetode moet voldoen en wat dan ook gebruik is as riglyne by die ontwikkeling van die nuwe markprysbepalingsmetode. Die vereistes het die volgende aspekte behels:

- prysbeslissings moet gekoppel word aan 'n hoeveelheidsbeslissing,

- herkenning van die faktore wat die opbrengswaarde en vervangingswaarde beinvloed,

- 'n bepaalde (spesifieke) bemarkingsbeleid en -strategie,

duidelik geïdentifiseerde doelmark,

- verteenwoordigende steekproeftrekking,

- goed-gekose respondente,

- realistiese winkelsituasie by ondersoek, en

- spesifieke aspekte rakende markprysbepalingsvrae

Hierdie inligting het dan die basis gevorm om 'n markprysbepalingsmetode te ontwikkel wat aan die vereistes sou voldoen en sewe stappe is onderskei by die uivoering van hierdie metode.

\section{Sewe stappe van die metode}

Definiëring van die markprysbepalingsdoelstellings en -situasie

Die eerste stap by die uitvoering van die markprysbepaling behels ' $n$ analise van en besluite oor die bemarkingsbeleid en -strategie van die produk waarvan die markprys te bepaal is. Die vereiste dat 'n spesifieke bemarkingsbeleid en -strategie geïmpliseer word, moet reeds op hierdie stadium aandag geniet. Die spesifieke produkbeleid, distribusiebeleid en bemarkingskommunikasiebeleid moet reeds hier vasgestel word.

\section{Identifisering van die doelmark}

Die tweede stap behels die besluit wat geneem moet word om die doelmark vas te stel, waarvoor 'n markprys bepaal moet word vir 'n spesifieke produk met 'n bepaalde bemarkingsbeleid en -strategie. Die doelmark moet so eng moontlik omskryf word ten einde die beste markprysbepalingsresultate te lewer.

\section{Verteenwoordigende steekproefgrootte}

Die derde stap behels die berekening van die steekproefgrootte wat verteenwoordigend van die gekose doelmark sal wees.

\section{Die samestelling van die vraeboog}

Die volgende inligting moet deel uitmaak van die vraeboog:

- 'n uiteensetting van die bepaalde produk en bemarkingsbeleid en -strategie wat geld;

- 'n reeks van pryse moet aan die respondent uitgeroep word waarop geantwoord moet word 'Ja, ek koop' of 'Nee, die prys is te laag of te hoog om te koop';

- inligting van elke respondent oor die prys wat laaste betaal is vir die produk; en

- enige bykomende inligting wat van belang beskou word en markprysresultate beter sal toelig.

Die volgende beginsels moet toegepas word tydens ondervraging:

- die bestaan van pryslimiete moenie voorgestel word deur die aard van die vrae nie;

- nie meer as tien pryse moet aan een respondent uitgeroep word nie;

- die eerste prys wat uitgeroep word moet die bestaande prys wees of 'n prys naby daaraan; en

- die res van die pryse moet ewekansig uitgeroep word.

Dit is noodsaaklik dat die vraelys skriftelik opgestel word sodat die ondervraer volgens 'n vasgestelde patroon sy vrae kan stel. Daar word dus van 'n gestruktureerde, 
vermomde vraelys gebruik gemaak.

\section{Die insameling van die gegewens (veldwerk)}

Die veldwerk vind plaas deur die aankoopproses waar te neem en kwalifiserende respondente daarná te ondervra. Die waarneming en ondervraging vir bestaande produkte behoort altyd in 'n werklike winkelsituasie plaas te vind, terwyl die winkelsituasie in die geval van nuwe produkte so goed moontlik gesimuleer moet word.

Die uitskakeling van respondente wat nie aan die gestelde vereistes voldoen nie, kan bewerkstellig word deur 'n kombinasie van die waarnemingsmetode en die opname-metode te gebruik by die insameling van die gegewens. Die ondervraer neem stelling in in ' $n$ onopsigtelike posisie in die winkel naby die uitstalling van die spesifieke produkte waarvan die markprys bereken wil word. Die ondervraer kan dus waarneem welke persone die spesifieke produk koop en gegewens soos handelsmerkkeuse en die prys betaal kan direk aangestip word, terwyl die persoon daarna genader kan word om die res van die vrae te beantwoord.

\section{Verwerking van die inligting en bepaling van die markprys}

Die verwerking van die antwoorde: 'Ja, ek sal koop' of 'Nee, die prys is te hoog of te laag' lewer drie funksies. $L(P)$

= die waarskynlikheid dat 'n lid van die gekose doelmark wat ewekansig verkies is, die produk as 'te goedkoop' sal beskou teen 'n prys $\boldsymbol{P}$.

$H(P)$ $=$ die waarskynlikheid dat 'n lid van die gekose doelmark wat ewekansig verkies is, die produk as 'te duur' sal beskou teen 'n prys $P$.

$B(P)=1-L(P)-H(P)=$ die waarskynlikheid dat 'n lid van die gekose doelmark wat ewekansig verkies is, die produk teen 'n prys $\boldsymbol{P}$ sal aankoop.

$L(P)$ word genoem die 'te laag'-distribusiefunksie en $\boldsymbol{H}(\boldsymbol{P})$ die 'te hoog'-distribusiefunksie terwyl $\boldsymbol{B}(\boldsymbol{P})$ die kooprespons-kromme is. Uit bogenoemde geld dat $0 \leqslant$ $L(P) \leqslant 1$ en $0 \leqslant H(P) \leqslant 1$ is, en indien die doelmark homogeen is, $H(P)$ monotonies sal toeneem en $L(P)$ monotonies sal afneem. Met hierdie gegewens beskikbaar, kan die kooprespons-kromme grafies voorgestel word.

Verskeie skrywers se navorsing dui daarop dat die persepsie van pryse deur verbruikers 'n logaritmiese skaal volg en die kooprespons-kromme moet dus min of meer met die normaalkromme ooreenstem. ${ }^{6}$ Indien substansiële afwyking van die normaalkromme voorkom, kan moontlike geleenthede of probleme geïdentifiseer word, wat vir die prysbepaler van groot nut kan wees.

Die markprys van 'n produk is die prys waarteen die meeste van die verbruikers bereid sal wees om die produk te koop (die draaipunt van die kooprespons-kromme).
Daar moet egter onthou word dat hierdie markprys nie noodwendig die beste prys vanuit 'n rentabiliteitsoogpunt sal wees nie.

Soos by die samestelling van die vraeboog aangetoon word, maak die metode ook voorsiening vir die insameling van die pryse wat laaste betaal is. Hierdie gegewens kan voorgestel word deur 'n prys-laaste-betaal-kromme. Die rede vir die insluiting van die vraag is dat daar vasgestel kan word wat die verband is tussen die houding van die verbruikers teenoor die produk se prys en die werklike prys wat hulle betaal het. Hierdie gegewens stel die bemarker in staat om te bepaal of die verbruikers tevrede is met die bestaande prys (prys-laaste-betaalkromme het dieselfde vorm as die kooprespons-kromme) of die prys as te hoog beskou (prys-laaste-betaal-kromme se toppunt lê regs van die markprys) of die prys as te laag beskou (prys-laaste-betaal-kromme se toppunt lê links van die markprys).

Uit die aard van die kooprespons-kromme word ook ondersteuning verkry vir die limiet-konsep, aangesien albei grense van die kooprespons-kromme nul nader waar of die kwaliteit van die produk onder verdenking kom of die hoeveelheid vervangingswaarde as te hoog beskou word in vergelyking met die opbrengswaarde wat dit bied.

Slegs een vereiste is nog in die metode afwesig, naamlik die koppeling van die prys aan 'n hoeveelheidsbeslissing. Indien daar geen mededinging vir die produk bestaan nie, kan die potensiële verkoopshoeveelheid direk van die kooprespons-kromme afgelei word. Indien die pryse en hoeveelhede van die verskillende mededingers bekend is, kan ' $n$ beraming gemaak word van die potensiële verkoopshoeveelheid van die produk deur dit voor te stel by die kooprespons-kromme met staafdiagramme vir elk van die onderskeie pryse van die mededingers.

\section{Opsomming van die resultate, gevolgtrekkings en aanbevelinge}

Die laaste stap by markprysbepaling is waar alle belangrike resultate (byvoorbeeld die markprys en verkoophoeveelheid; evaluering van die bestaande prys deur die verbruikers; moontlike geleenthede of bedreigings) op skrif gestel word en aanbevelinge aan die bemarkingsbestuur voorgelê word. Hierdie markprysgegewens kan bestuur dan help om deur versoening van die markprys en doelwitprys besluite te neem oor die finale prys waarteen die produk op die mark aangebied sal word.

\section{Die emplriese verifikasie van die nuwe metode}

Die nuwe markprysbepalingsmetode se praktiese toepassing is getoets deur die markpryse te bepaal vir twee onduursame verbruikersgoedere in 'n werklike winkelsituasie. Die ondersoek word bespreek aan die hand van die sewe stappe wat in die metode gevolg is.

1. Definiëring van die markprysbepalingsdoelstellings en -omstandighede

Ten aanvang moes besluit word watter onduursame verbruikersgoedere se markpryse bepaal moet word, asook die plek waar die ondersoek moet plaasvind. Die belangrikste oorweging by die keuse was om die bemarkingsbe- 
leid en -strategie van die produkte so spesifiek moontlik te stel. Daar is toe besluit om die markpryse van twee onduursame verbruikersgoedere in 'n spesifieke kleinhandelsonderneming (supermark) te bepaal.

Op grond van sekere bepalende faktore is twee produkte gekies waarvan die ondersoekomstandighede die beste sou wees. Hierdie faktore het onder andere die gunstige rakligging vir waarneming en ondervraging; voldoende mededingende produkte; prysgapings tussen produkte wat nie te groot is nie; nie te veel mededingende produkte nie; hoë aankoopfrekwensie; en die minste ontwrigting vir die werksaamhede van die personeel van die supermark, ingesluit. Op grond van bogenoemde faktore is besluit om die markpryse te bepaal vir 'n $750 \mathrm{ml}$-bottel kookolie en 'n $750 \mathrm{ml}$-bottel skottelgoedopwasmiddel.

Die vereiste vir 'n spesifieke produk en bemarkingsbeleid en -strategie is dus nagekom. Eerstens was daar 'n spesifieke produk waarvan die prys bepaal moes word. Tweedens is 'n spesifieke distribusiebeleid en -strategie veronderstel (in hierdie geval is slegs hierdie supermark spesifiek as distribusiepunt aan die respondente gestel), met derdens 'n gegewe bemarkingskommunikasiebeleid en -strategie.

\section{Identifisering van die doelmark}

By die besluite oor die doelmarkte wat vir die twee produkte geïdentifiseer moes word, is gepoog om eerstens die grootste doelmark te kies ten einde die meeste prysinligting te verkry, maar tweedens nog daarna te streef om die doelmark so eng moontlik te omskryf. Aangesien huisvroue gewoonlik die kruideniersaankope verrig, was hul die aangewese doelmark. Die doelmarkte vir elk van die twee produkte is as volg omskryf:

Kookolie

- Blanke huisvroue wat 'n 750 ml-bottel kookolie by die bepaalde winkel aankoop

Skottelgoed- Blanke huisvroue wat 'n 750 opwasmiddel ml-bottel skottelgoedopwasmiddel in die bepaalde winkel aankoop

\section{Die grootte van die steekproeftrekking}

Daar is besluit om 200 respondente ten opsigte van elke produk te ondervra. Deur gebruikmaking van inligting wat deur die bestuur van die supermark verskaf is, kon die totale doelmark vir een maand as volg beraam word:
Kookolie
- 1029 verbruikers
Skottelgoedopwasmiddel $\quad-\quad 900$ verbruikers

Daar is dus na raming in die geval van kookolie $19,4 \%$ n van die totale doelmark ondervra en in die geval van skottelgoedopwasmiddels $22,2 \%$. Verbruikers moes antwoorde verskaf op sewe pryse elk sodat by elkeen van die twee produkte 1400 prys-antwoorde verskaf is.

By die uitvoering van hierdie ondersoek is gepoog om die metode van markprysbepaling te toets, met ander woorde die hoofoogmerk was die illustrasie van die metode en nie die berekening van die werklike markpryse nie. Die markpryse wat bereken is en die afleidings en aanbevelinge wat gemaak word, moet dus nie beskou word as die werklike markpryse van die produkte nie. Daar sou slegs daarop aanspraak gemaak kan word dat die berekende markpryse wel die werklike markpryse ver- teenwoordig, indien bewys sou kon word dat die steekproefgrootte verteenwoordigend van die doelmark was.

Die vraag wat nou kan ontstaan is of die aantal respondente en veral die aantal prys-antwoorde wat by respondente verkry is, voldoende is om die werking van die metode te kan bewys. Geoordeel bloot aan die ooreen stemmende resultate wat verkry is in vergelyking met die van die ander markprysbepalingsmetodes, en veral dié van Gabor en Granger,' kan aanvaar word dat 'n voldoende aantal respondente ondervra is.

\section{Die samestelling van die vraeboè}

Die vraeboë wat gebruik is, is twee keer getoets en probleme wat voorgekom het, is uitgeskakel voor die finale vorm van die vraeboë vasgestel is. Die vraeboë het in alle opsigte voldoen aan die vereistes gestel by die samestelling van die vraeboog. Vraag een kon ingevul word deur die blote waarneming van die verbruiker en die korrekte prysinligting (wat voor die tyd ingevul was en gekontroleer is nadat die ondersoek afgehandel is) oor die prys wat laaste betaal is, is sodoende ingewin.

Vraag twee het eerstens 'n uiteensetting gegee van die bepaalde produk en bemarkingsbeleid en -strategie wat geld, terwyl 'n reeks van pryse verder aan die respondent uitgeroep is waarop die antwoord ' Ja, ek koop' of 'Nee, die prys is te laag of te hoog', verkry is.

Die bestaan van die pryslimiete is nie voorgestel deur die aard van die vrae nie, terwyl slegs sewe pryse aan elke respondent uitgeroep is. Die eerste prys wat uitgeroep was, was 'n prys naby die bestaande prys terwyl die keuse van die ses ander pryse bepaal is aan die hand van ewekansige tabelle. In die geval van skottelgoedopwasmiddel is verwag dat die aanwesigheid van ' $n$ bediende al dan nie in die huishouding, ' $n$ belangrike invloed op die huisvroue se aankoopsbesluit sal uitoefen, en gevolglik is 'n vraag hieroor in die vraeboog ingesluit.

\section{Die insameling van die inligting}

Gegewens is verkry deur die vraeboë te voltooi volgens 'n vasgestelde prosedure. 'n Kombinasie van die waarnemingsmetode en die opname-metode by die uitvoering van 'n formele ondersoek is gebruik. Die ondervraer het stelling ingeneem in so ' $n$ posisie dat hy presies kon sien watter handelsmerk van die besondere produk aangekoop word, sonder dat die verbruiker kon agterkom dat sy dopgehou word en gevolglik onnatuurlik optree. Die soort handelsmerk en gevolglike prys wat laaste betaal is, is onmiddellik op die gestruktureerde vraeboog afgemerk, waarna die responent genader is om die res van die vrae mondelings te beantwoord. Die voordeel hiervan is dat slegs respondente ondervra is wat wel so 'n produk aangekoop het en gevolglik die verlangde inligting kon voorsien. Die aankoopsbesluit (handelsmerkkeuse sowel as pryskeuse) het in ' $n$ werklike winkelsituasie plaasgevind en die empiriese ondersoek het dus geen invloed op hierdie resultate uitgeoefen nie.

In die geval van kookolie is respondente oor 'n tydperk van vier dae ondervra, waartydens alle faktore konstant gehou is. Die respondente van skottelgoedopwasmiddels is oor 'n tydperk van drie en 'n half dae ondervra waartydens alle faktore ook konstant gebly het. Volgens die bestuur van die supermark was die pryse van skottelgoedopwasmiddels redelik konstant voor die empiriese onder- 
soek, maar is afslagkoepons vir hierdie soort produk gereeld tydens spesiale promosies in die winkel uitgedeel, terwyl kookolie 'n redelike prysstyging een maand voor die ondersoek ondergaan het.

6. Die verwerking en voorstelling van die inligting

\section{Gevolgtrekkings en afleidings}

Stappe ses en sewe van die metode word gesamentlik bespreek ten einde die kontinuïteit beter te handhaaf. In Tabelle 1 en 2 word 'n opsomming gegee van die verwerkte resultate wat vanaf die kookolie-respondente verkry is.

Daar was ses handelsmerke van kookolie in $750 \mathrm{ml}$ bottels beskikbaar en die pryse het gewissel vanaf $92 \mathrm{c}$ tot R1,22. Pryse wat genoem moes word is vasgestel met $4 c$-intervalle gesentreer om die rekenkundige gemiddeld van al die pryse van die mededingende produkte. In die vasstelling van die pryse is gepoog om nie van 'ronde pryse' (byvoorbeeld $R 1,00$ en $R 1,50$ ) gebruik te maak nie omdat dit dalk die antwoorde kon beïnvloed. Daar is besluit om 20 pryse vas te stel waaroor prysbeslissings gemaak moes word.

Tabel 1 Frekwensie van aankope volgens handelsmerk: kookolie

\begin{tabular}{lccc}
\hline & \multicolumn{2}{c}{ Prys laaste betaal } & \\
\cline { 2 - 4 } \multicolumn{1}{c}{ Handelsmerk } & Prys & Hoeveelheid & $\%$ \\
\hline Pantry Pride & $92 \mathrm{c}$ & 152 & 76 \\
Cotona & $93 \mathrm{c}$ & 13 & 6,5 \\
Epic & $97 \mathrm{c}$ & 22 & 11 \\
Cardin & $104 \mathrm{c}$ & 2 & 1 \\
Solo & $112 \mathrm{c}$ & 7 & 3,5 \\
Covo & $122 \mathrm{c}$ & 4 & 2 \\
\hline
\end{tabular}

Tabel 2 Prysrespons van alle kookolie-respondente

\begin{tabular}{|c|c|c|c|c|c|c|c|}
\hline \multirow[b]{2}{*}{$\begin{array}{l}\text { Pryse } \\
\text { genoem }\end{array}$} & \multirow[b]{2}{*}{$\begin{array}{l}\text { Sal } \\
\text { koop }\end{array}$} & \multirow[b]{2}{*}{$\begin{array}{c}\text { Te } \\
\text { hoog }\end{array}$} & \multirow[b]{2}{*}{$\begin{array}{c}\mathrm{Te} \\
\text { laag }\end{array}$} & \multirow[b]{2}{*}{ Totaal } & \multicolumn{3}{|c|}{$\begin{array}{c}\text { Persentasies } \\
\text { (afgerond tot } 0,5 \text { ) }\end{array}$} \\
\hline & & & & & Koop & $\begin{array}{c}\text { Te } \\
\text { hoog }\end{array}$ & $\begin{array}{c}\mathrm{Te} \\
\text { laag }\end{array}$ \\
\hline $61 \mathrm{c}$ & 49 & 0 & 8 & 57 & 86 & 0 & 14 \\
\hline $65 c$ & 65 & 0 & 14 & 79 & 82,5 & 0 & 17,5 \\
\hline $69 c$ & 61 & 0 & 6 & 67 & 91 & 0 & 9 \\
\hline $73 \mathrm{c}$ & 57 & 0 & 3 & 60 & 95 & 0 & 5 \\
\hline $77 \mathrm{c}$ & 63 & 0 & 9 & 72 & 87,5 & 0 & 12,5 \\
\hline $81 \mathrm{c}(\mathrm{MP})$ & P) 58 & 1 & 2 & 61 & 95 & 1,5 & 3,5 \\
\hline$\overline{85 c}$ & 54 & 3 & 3 & 60 & 90 & 5 & 5 \\
\hline $89 c$ & 70 & 2 & 3 & 75 & 93,5 & 2,5 & 4 \\
\hline $93 \mathrm{c}$ & 58 & 10 & 4 & 72 & 80,5 & 14 & 5,5 \\
\hline $97 c$ & 38 & 20 & 1 & 59 & 64,5 & 34 & 1,5 \\
\hline $101 \mathrm{c}$ & 15 & 42 & 2 & 59 & 25,5 & 71 & 3,5 \\
\hline $105 c$ & 14 & 59 & 1 & 74 & 19 & 80 & 1 \\
\hline $109 x$ & 19 & 96 & 2 & 117 & 16 & 82 & 2 \\
\hline $113 c$ & 9 & 71 & 1 & 81 & 11 & 87,5 & 1,5 \\
\hline $117 \mathrm{c}$ & 7 & 66 & 0 & 73 & 9,5 & 90,5 & 0 \\
\hline 12 Ic & 3 & 72 & 0 & 75 & 4 & 96 & 0 \\
\hline $125 c$ & 3 & 65 & 0 & 68 & 4,5 & 95,5 & 0 \\
\hline $129 \mathrm{c}$ & 4 & 57 & 0 & 61 & 6,5 & 93,5 & 0 \\
\hline $133 c$ & 1 & 63 & 0 & 64 & 1,5 & 98,5 & 0 \\
\hline $137 \mathrm{c}$ & 1 & 65 & 0 & 66 & 1,5 & 98,5 & 0 \\
\hline
\end{tabular}

In Tabelle 3 en 4 word 'n opsomming gegee van die verwerkte resultate van al die respondente wat 'n $750 \mathrm{ml}$ bottel skottelgoedopwasmiddel aangekoop het. In die spesifieke supermark is sewe mededingende handelsmerke van die spesifieke grootte skottelgoedopwasmiddel te koop aangebied. Pryse het gewissel vanaf $36 \mathrm{c}$ tot $84 \mathrm{c}$. Genoemde pryse is vasgestel met $5 \mathrm{c}$-intervalle weerskante van die rekenkundige gemiddeld. Soos in die geval van kookolie is gepoog om 'ronde pryse' uit te skakel en is 20 pryse vasgestel.

Tabel 3 Frekwensie van aankope volgens handelsmerk: skottelgoedopwasmiddel

\begin{tabular}{|c|c|c|c|c|}
\hline \multirow[b]{2}{*}{ Handelsmerk } & \multicolumn{2}{|c|}{ Prys laaste betaal } & \multirow{2}{*}{\multicolumn{2}{|c|}{$\%$}} \\
\hline & Prys & Hoeveelheid & & \\
\hline Jills & $36 c$ & 16 & 8 & \\
\hline Klentz & $49 \mathrm{c}$ & 3 & 1,5 & \\
\hline Gosh & 5lc & 12 & 6 & \\
\hline Shelley & $62 c$ & 19 & 9,5 & \\
\hline Daisy & $67 c$ & 28 & 14 & \\
\hline Ajax & $84 c$ & 8 & & 4 \\
\hline Sunlight Liquid & $84 c$ & \begin{tabular}{l|l}
114 & 122
\end{tabular} & 61 & 57 \\
\hline
\end{tabular}

Tabel 4 Prysrespons van alle skottelgoedopwasmiddel-respondente

\begin{tabular}{|c|c|c|c|c|c|c|c|}
\hline \multirow[b]{2}{*}{$\begin{array}{c}\text { Pryse } \\
\text { genoem }\end{array}$} & \multirow[b]{2}{*}{$\begin{array}{l}\text { Sal } \\
\text { koop }\end{array}$} & \multirow[b]{2}{*}{$\begin{array}{c}\text { Te } \\
\text { hoog }\end{array}$} & \multirow[b]{2}{*}{$\begin{array}{c}\text { Te } \\
\text { laag }\end{array}$} & \multirow[b]{2}{*}{ Totaal } & \multicolumn{3}{|c|}{$\begin{array}{c}\text { Persentasies } \\
\text { (afgerond tot } 0,5 \text { ) }\end{array}$} \\
\hline & & & & & Koop & $\begin{array}{c}\mathrm{Te} \\
\text { hoog }\end{array}$ & $\begin{array}{l}\text { Te } \\
\text { laag }\end{array}$ \\
\hline 11 & 6 & 0 & 73 & 79 & 7.5 & 0 & 92,5 \\
\hline 16 & 9 & 0 & 73 & 82 & 11 & 0 & 89 \\
\hline 21 & 5 & 0 & 45 & 50 & 10 & 0 & 90 \\
\hline 26 & 5 & 0 & 49 & 54 & 9,5 & 0 & 90,5 \\
\hline 31 & 9 & 0 & 42 & 51 & 17,5 & 0 & 82,5 \\
\hline 36 & 16 & 0 & 51 & 67 & 24 & 0 & 76 \\
\hline 41 & 20 & 1 & 37 & 58 & 34,5 & 1,5 & 64 \\
\hline 46 & 27 & 0 & 49 & 76 & 35,5 & 0 & 64,5 \\
\hline 51 & 44 & 5 & 29 & 78 & 56,5 & 6,5 & 37 \\
\hline 56 & 50 & 7 & 23 & 80 & 62,5 & 8,5 & 29 \\
\hline 61 & 45 & 11 & 6 & 62 & 72,5 & 17,5 & 10 \\
\hline 66 & 54 & 12 & 5 & 71 & 76 & 17 & 7 \\
\hline 71 & 48 & 14 & 0 & 62 & 77,5 & 22,5 & 0 \\
\hline$\underline{76}(\mathrm{MP})$ & 63 & 15 & 1 & 79 & $\underline{79,5}$ & 19 & 1,5 \\
\hline 81 & 46 & 29 & 1 & 76 & $\overline{60,5}$ & 38 & 1,5 \\
\hline 86 & 45 & 35 & 0 & 80 & 56 & 44 & 0 \\
\hline 91 & 18 & 66 & 0 & 84 & 21,5 & 78,5 & 0 \\
\hline 96 & 5 & 54 & 0 & 59 & 8,5 & 91,5 & 0 \\
\hline 101 & 3 & 67 & 0 & 70 & 4,5 & 95,5 & 0 \\
\hline 106 & 1 & 81 & 0 & 82 & 1 & 99 & 0 \\
\hline
\end{tabular}

Vasstelling van die prysreekse en intervalle

Uit die aard van die antwoorde wat ontvang is, wil dit voorkom asof die prysreeks en -intervalle in die geval van die skottelgoedopwasmiddel-ondersoek voldoende vasgestel was, maar in die geval van die kookolie-ondersoek die pryse op die vraeboog nie laag genoeg vasgestel was nie.

Die bewys vir hierdie afleiding word verkry in die kumulatiewe persentasie respondente wat die genoemde pryse as te hoog of te laag beskou het. By kookolie het 
geen respondent die laagste prys as te hoog beskou nie, terwyl $98,5 \%$ van die respondente die hoogste genoemde prys as te hoog beskou het. Alhoewel geen respondent vanaf die sesde hoogste prys $(R 1,17)$ die prys as te laag beskou het nie, het slegs $17 \%$ van die respondente $65 \mathrm{c}$ as te laag beskou.

In die geval van die skottelgoedopwasmiddel-respondente het geen respondent die laagste genoemde prys as te hoog beskou nie, terwyl $99 \%$ die hoogste prys as te hoog beskou het. Die laagste prys is deur $92,5 \%$ as te laag beskou, terwyl geen respondent die hoogste prys as te laag beskou het nie. Die inligting kan ook grafies voorgestel word deur 'te hoog'- en 'te laag'-distribusiefunksies. ${ }^{1,}$ pp.96.99

Uit hierdie resultate kan die bestaan van die pryslimiete dus duidelik gesien word, behalwe vir die lae pryslimiet in die geval van kookolie. Die redes hiervoor is eerstens dat die hoër geprysde handelsmerke kookolie die rekenkundige gemiddeld ongebalanseerd verhoog het teenoor die groot markaandeel van die lae prys handelsmerke en tweedens omdat die prysintervalle groter vasgestel moes word as $4 c$ per prysverandering. Dit sou egter tot gevolg gehad het dat die ontleding van die pryse in minder detail kon plaasvind.

\section{Markpryse en die kooprespons-kromme}

Die kooprespons-kromme en die prys-laaste-betaalkromme van die kookolie-respondente word aangetoon in Figuur 1 en dié van die skottelgoedopwasmiddelrespondente in Figuur 2.

Die hoogste persentasie bevestigende antwoorde $(95,08 \%$ en $79,5 \%$ onderskeidelik in die geval van kookolie en skottelgoedopwasmiddel) bepaal die markpryse vir die produkte. Hiervan kan afgelei word dat die markprys van kookolie $81 \mathrm{c}$ is en die markprys van die skottelgoedopwasmiddel 76c. Hierdie markpryse is nie vir 'n spesifieke handelsmerk nie, maar vir 'n $750 \mathrm{ml}$-bottel kookolie en skottelgoedopwasmiddel.

Uit die kooprespons-krommes kan ook gesien word dat by elk van die produkte 'n wye reeks pryse vir 'n groot deel van die respondente aanvaarbaar is. By kookolie is 'n prys vanaf $61 \mathrm{c}$ tot $93 \mathrm{c}$ aanvaarbaar vir tussen 86 en $80,5 \%$ van die respondente, waarna die aanvaarbaarheid van hoër pryse skerp daal. By die skottelgoedopwasmiddels is 'n prys vanaf $61 \mathrm{c}$ tot $76 \mathrm{c}$ aanvaarbaar vir tussen 62,5 en $79,5 \%$ van die respondente.

Wanneer die vorm van die kooprespons-krommes vergelyk word met die algemene normaalkromme se vorm kan die volgende afleidings gemaak word: Indien die kooprespons-kromme met 'n verskeidenheid mededingers in 'n mate simmetries voorkom, bewys dit dat die verbruikers oor die algemeen tevrede is met bestaande pryse. ${ }^{7}$ Dit blyk dus duidelik dat die verbruikers van skottelgoedopwasmiddels redelik tevrede is met die bestaande pryse, terwyl die verbruikers van kookolie duidelik die produk as te hoog geprys beskou, of kookolie as 'n uniforme produk beskou.

\section{Kooprespons- en prys-laaste-betaal-krommes}

Die ooreenstemming tussen die kooprespons-krommes en die prys-laaste-betaal-kromme verleen ook belangrike inligting aan die prysbepaler. Die ooreenkoms tussen die ene vorm van die kooprespons-kromme en die prys-

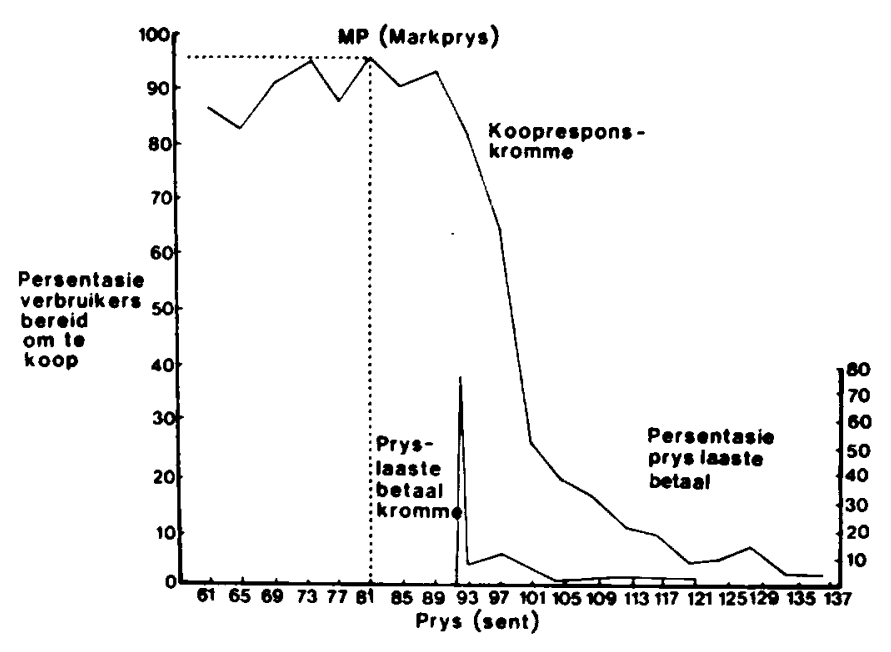

Figuur 1 Kooprespons-kromme en prys-laaste-betaal-kromme van kookolie-respondente

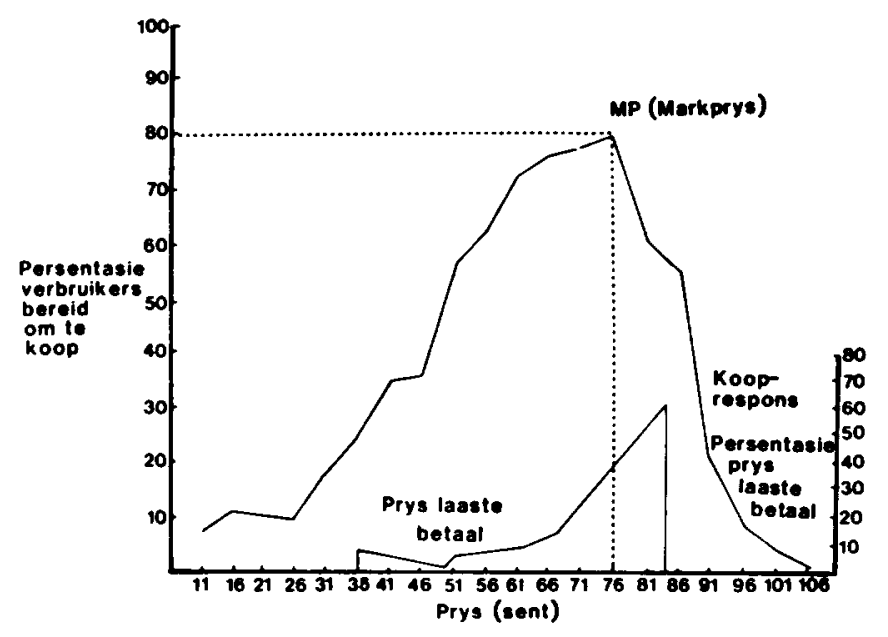

Figuur 2 Kooprespons-kromme en prys-laaste-betaal-kromme van alle skottelgoedopwasmiddel-respondente

laaste-betaal-kromme blyk duidelik uit Figure 1 en 2.

Die afleiding kan dus hieruit gemaak word dat die verbruikers van die produkte wel bestaande pryse van die produkte in ag geneem het by die beoordeling van hul pryskeuses. 'n Hoë mate van korrelasie tussen die kooprespons-kromme en die prys-laaste-betaal-kromme dui daarop dat die respondente die prys wat hul betaal het, gebruik het as 'n belangrike determinant in hul prysbeslissings. Nog 'n rede vir die ooreenstemming is dat weens die metode wat gevolg is in die ondersoek, die korrekte pryse wat laaste betaal is, aangestip is. Alhoewel daar 'n groot mate van korrelasie tussen die prys-laastebetaal-kromme en die kooprespons-kromme bestaan, sal die kooprespons-kromme nooit absoluut afgelei kan word van die prys-laaste-betaal-kromme nie. ${ }^{5 p \$ 8}$

In die vergelyking van die prys-laaste-betaal-krommes met dié van die kooprespons-kromme, word gesien dat die pieke van die prys-laaste-betaal-kromme na regs lê van die pieke van die kooprespons-kromme (markprys). Albei produkte word dus as te hoog geprys beskou. Kookolie word egter baie meer as te hoog geprys beskou as skottelgoedopwasmiddel. Verskeie redes kan vir hierdie verskynsel verantwoordelik wees.

Eerstens kan die verskil voorkom as gevolg van 'n te klein steekproeftrekking. Tweedens mag dit wees dat die prys wat die populêrste sou wees, nie ingesluit was in die 
prysreeks nie. Derdens is dit moontlik dat handelsmerke wat geprys is naby die markprys, nie in die spesifieke supermark te koop aangebied word nie. ' $n$ Vierde rede is dat die laer markprys van skottelgoedopwasmiddels veroorsaak word deur die laer geprysde handelsmerke wat die piek van die kooprespons-kromme na links skuif. Vyfdens is die prys-laaste-betaal-kromme vir kookolie vervolgens so ver na regs aangesien daar nie goedkoper handelsmerke beskikbaar is nie. Sesdens wil dit voorkom asof daar nie baie kwaliteitsverskil persepteer word in die kookoliemark nie, terwyl groot kwaliteitsverskil wel persepteer word in die geval van skottelgoedopwasmiddels. ' $n$ Sewende rede is dat weens spesiale aanbiedinge wat gereeld by hierdie produkte voorkom, ' $n$ laer prys as aanvaarbaar beskou word. Nog 'n belangrike rede waaroor kookolie as te hoog geprys beskou is, is die feit dat volgens die bestuur van die supermark, kookolie 'n redelike groot prysstyging in die maand wat die ondersoek voorafgegaan het ondergaan het. Verbruikers het dus nog nie kans gehad om hul aan te pas of te versoen met die nuwe prysvlak nie.

'n Laaste betekenisvolle afleiding kan gemaak word uit die resultate van skottelgoedopwasmiddels. Die feit dat meer as $60 \%$ van die respondente 'n duurder prys as die markprys betaal het dui daarop dat die goedkoper handelsmerke nie die kwaliteit lewer wat die meeste respondente vereis nie; die verbruikers is dus bereid om 'n premie te betaal vir 'n hoër kwaliteit skottelgoedopwasmiddel.

\section{Markaandeel en geleenthede in markte}

Alle aspekte dui daarop dat daar baie geleenthede in albei die markte vir bemarkers bestaan. Indien enige van die leidende handelsmerke wat reeds ' $n$ goeie kwaliteitsbeeld opgebou het hul prys verminder, behoort hul 'n substansiële markaandeel van die totale mark te bekom. Die gevaar bestaan egter dat verbruikers ook 'n vermindering in kwaliteit sal waarneem.

Die markaandeel van elke mededinger word ooreenkomstig hul pryse aangetoon met staafdiagramme in Figure 3 en 4. Deur dit saam met die koopresponskrommes voor te stel kan geleenthede in die mark duidelik geïdentifiseer word. Die totale persentasies markaandeel van elke produk is aangetoon in Tabelle 1 en 3. Daar is ' $n$ beduidende handelsmerkleier in elk van die twee markte. Pantry Pride het 76\% markaandeel in kookolieverkope en Sunlight Liquid $56 \%$ in skottelgoedopwasmiddelverkope.

Pantry Pride is die enigste handelsmerk kookolie naby die markprys. Daar bestaan dus besondere markpotensiaal vir 'n laer-geprysde handelsmerk kookolie. Uit die skottelgoedopwasmiddel-resultate kan gesien word dat Ajax, Shelly en Daisy nie hul potensiële markaandeel geniet nie en dus of hul kwaliteit moet verbeter, ò hul bemarkingskommunikasiepogings moet verskerp en verbeter. So ook in 'n mindere mate Klentz en Gosh.

Aangesien daar verwag is dat die feit of ' $n$ respondent ' $n$ bediende het of nie, ' $n$ belangrike invloed op die respondent se prysbeslissings en handelsmerkkeuse sou uitoefen, is besluit om hierdie respondente se gegewens ook afsonderlik te ontleed. Van die skottelgoedopwasmiddel-respondente het 95 ' $n$ bediende gehad terwyl 105 hul eie skottelgoed opgewas het.

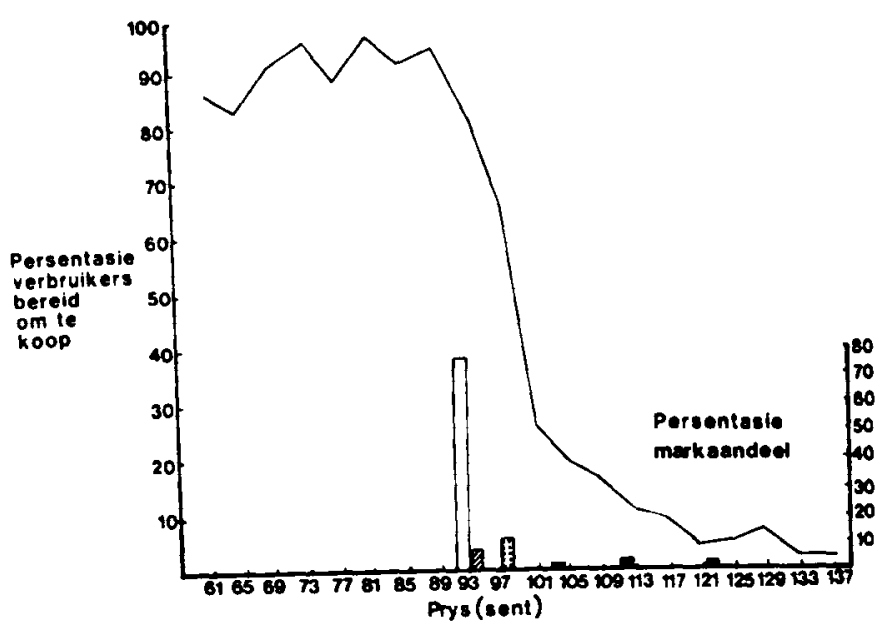

Figuur 3 Kooprespons-kromme met markaandeel van alle handelsmerke: kookolie

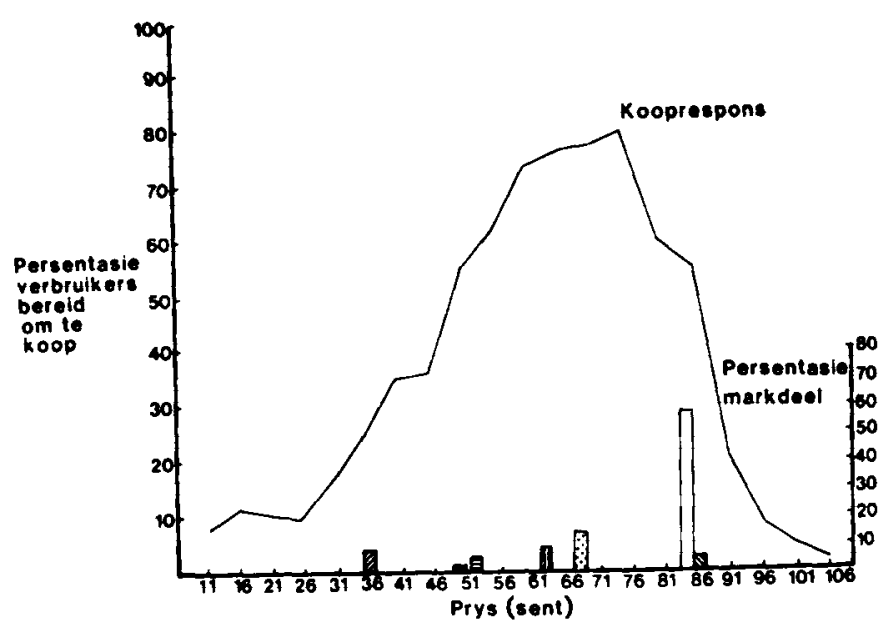

Figuur 4 Kooprespons-kromme met markaandeel van alle skottelgoedopwasmiddel-handelsmerke

\section{Skottelgoedopwasmiddel-respondente: met en sonder bediendes}

Die gegewens verkry vanaf respondente met bediendes word aangetoon in Tabelle 5 en 6, terwyl die gegewens verkry vanaf respondente sonder bediendes aangetoon word in Tabelle 7 en 8.

Uit die ontleding van die resultate van die skottelgoedopwasmiddel-respondente met en sonder bediendes kom dit voor asof die mark vir skottelgoedopwasmiddels basies uit ' $n$ lae-prys en hoë-kwaliteit subdoelmark bestaan, terwyl die middelprysdoelmark ' $n$ baie klein deel van die totale mark uitmaak. Die lae markaandeel van die laer-geprysde handelsmerke geld slegs in die mark vir $\mathbf{7 5 0}$ ml-skottelgoedopwasmiddels. Weens die swakker kwaliteit word hierdie handelsmerke in groter hoeveelhede verbruik en verkoop en besit hulle die grootste markaandeel in die $2 \mathrm{l}$ - en $5 \mathrm{l}$-verpakkings. Weens die gekonsentreerdheid van Sunlight Liquid word dit slegs in $750 \mathrm{ml}$ - en 500 ml-verpakkings bemark.

Die kooprespons-kromme en prys-laaste-betaalkromme vir die respondente met bediendes word in Figuur 5 aangetoon, terwyl die krommes vir die respondente sonder bediendes in Figuur 6 voorgestel word.

Die markprys vir respondente met bediendes bedra 51c en dié vir respondente sonder bediendes, 76c. Hierdie 
Tabel 5 Frekwensie van aankope volgens handelsmerk: skottelgoedopwasmiddel-respondente met bediendes

\begin{tabular}{lccc}
\hline & \multicolumn{2}{c}{ Prys laaste betaal } & \\
\cline { 2 - 4 } \multicolumn{1}{r}{ Handelsmerk } & Prys & Hoeveelheid & $\%$ \\
\hline Jills & $36 \mathrm{c}$ & 16 & 17 \\
Klentz & $49 \mathrm{c}$ & 3 & 3 \\
Gosh & $51 \mathrm{c}$ & 10 & 10,5 \\
Shelley & $62 \mathrm{c}$ & 13 & 13,5 \\
Daisy & $67 \mathrm{c}$ & 21 & 22,5 \\
Ajax & $84 \mathrm{c}$ & & \\
Sunlight Liquid & $84 \mathrm{c}$ & 32 & 33,5 \\
\hline
\end{tabular}

Tabel 6 Prysrespons van skottelgoedopwasmiddel-respondente met bediendes

\begin{tabular}{|c|c|c|c|c|c|c|c|}
\hline \multirow[b]{2}{*}{$\begin{array}{c}\text { Pryse } \\
\text { genoem }\end{array}$} & \multirow[b]{2}{*}{$\begin{array}{c}\text { Sal } \\
\text { koop }\end{array}$} & \multirow[b]{2}{*}{$\begin{array}{c}\text { Te } \\
\text { hoog }\end{array}$} & \multirow[b]{2}{*}{$\begin{array}{c}\mathrm{Te} \\
\text { laag }\end{array}$} & \multirow[b]{2}{*}{ Totaal } & \multicolumn{3}{|c|}{$\begin{array}{c}\text { Persentasies } \\
\text { (afgerond tot } 0,5 \text { ) }\end{array}$} \\
\hline & & & & & Koop & $\begin{array}{c}\text { Te } \\
\text { hoog }\end{array}$ & $\begin{array}{l}\text { Te } \\
\text { laag }\end{array}$ \\
\hline 11 & 4 & 0 & 31 & 35 & 11,5 & 0 & 88,5 \\
\hline 16 & 7 & 0 & 37 & 44 & 16 & 0 & 84 \\
\hline 21 & 4 & 0 & 15 & 19 & 21 & 0 & 79 \\
\hline 26 & 4 & 0 & 21 & 25 & 16 & 0 & 84 \\
\hline 31 & 9 & 0 & 15 & 24 & 37,5 & 0 & 62,5 \\
\hline 36 & 13 & 0 & 19 & 32 & 40,5 & 0 & 59,5 \\
\hline 41 & 13 & 1 & 9 & 23 & 56,5 & 4,5 & 39 \\
\hline 46 & 21 & 0 & 11 & 32 & 65,5 & 0 & 34,5 \\
\hline$\underline{s 1}(\mathrm{MP})$ & 28 & 5 & 3 & 36 & 78 & 14 & 8 \\
\hline$\overline{56}$ & 27 & 6 & 4 & 37 & $\overline{73}$ & 16 & 11 \\
\hline 61 & 22 & 9 & 2 & 33 & 66,5 & 27,5 & 6 \\
\hline 66 & 29 & 11 & 4 & 44 & 66 & 25 & 9 \\
\hline 71 & 16 & 11 & 0 & 27 & 59,5 & 40,5 & 0 \\
\hline 76 & 22 & 13 & 0 & 35 & 63 & 37 & 0 \\
\hline 81 & 12 & 26 & 1 & 39 & 31 & 66,5 & 2,5 \\
\hline 86 & 12 & 26 & 0 & 38 & 31,5 & 68,5 & 0 \\
\hline 91 & 3 & 42 & 0 & 45 & 6,5 & 93,5 & 0 \\
\hline 96 & 2 & 30 & 0 & 32 & 6,5 & 93,5 & 0 \\
\hline 101 & 0 & 31 & 0 & 31 & 0 & 100 & 0 \\
\hline 106 & 0 & 34 & 0 & 34 & 0 & 100 & 0 \\
\hline
\end{tabular}

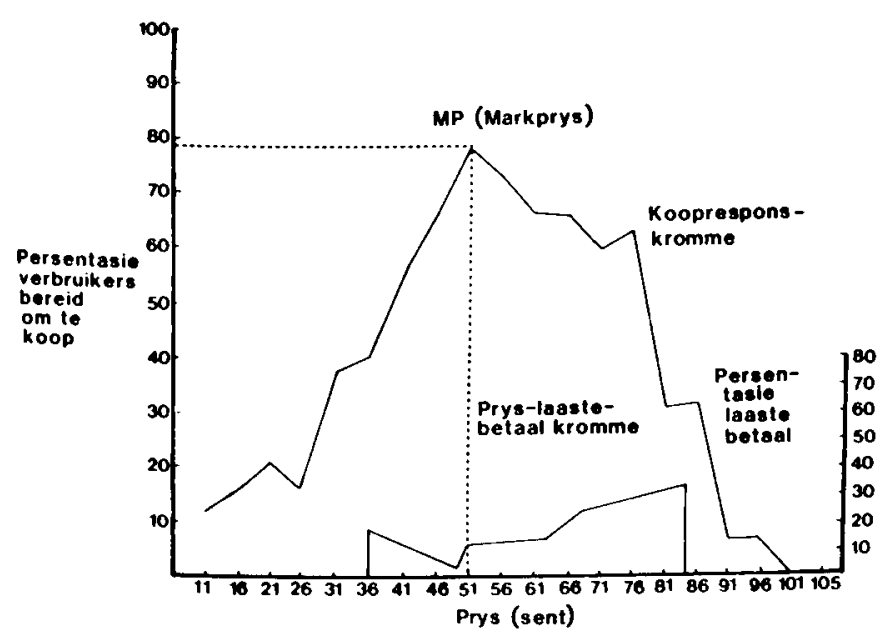

Figuur 5 Kooprespons-kromme en prys-laaste-betaal-kromme: respondente met bediendes
Tabel 7 Frekwensie van aankope volgens handelsmerk: skottelgoedopwasmiddel-respondente sonder bediendes

\begin{tabular}{lccc}
\hline \multirow{2}{*}{ Handelsmerk } & \multicolumn{2}{c}{ Prys laaste betaal } & \\
\cline { 2 - 4 } Jills & Prys & Hoeveelheid & $\%$ \\
Klentz & $36 c$ & 0 & 0 \\
Gosh & $49 c$ & 0 & 0 \\
Shelley & $51 \mathrm{c}$ & 2 & 2 \\
Daisy & $62 \mathrm{c}$ & 6 & 5,5 \\
Ajax & $67 \mathrm{c}$ & 7 & 6,5 \\
Sunlight Liquid & $84 \mathrm{c}$ & & \\
\hline
\end{tabular}

Tabel 8 Prysrespons van skottelgoedopwasmiddel-respondente sonder bediendes

\begin{tabular}{|c|c|c|c|c|c|c|c|}
\hline \multirow[b]{2}{*}{$\begin{array}{c}\text { Pryse } \\
\text { genoem }\end{array}$} & \multirow[b]{2}{*}{$\begin{array}{c}\text { Sal } \\
\text { koop }\end{array}$} & \multirow[b]{2}{*}{$\begin{array}{c}\text { Te } \\
\text { hoog }\end{array}$} & \multirow[b]{2}{*}{$\begin{array}{c}\text { Te } \\
\text { laag }\end{array}$} & \multirow[b]{2}{*}{ Totaal } & \multicolumn{3}{|c|}{$\begin{array}{c}\text { Persentasies } \\
\text { (afgerond tot } 0,5 \text { ) }\end{array}$} \\
\hline & & & & & Koop & $\begin{array}{c}\mathrm{Te} \\
\text { hoog }\end{array}$ & $\begin{array}{c}\text { Te } \\
\text { laag }\end{array}$ \\
\hline 11 & 2 & 0 & 42 & 44 & 4,5 & 0 & 95,5 \\
\hline 16 & 2 & 0 & 36 & 38 & 5,5 & 0 & 94,5 \\
\hline 21 & 1 & 0 & 30 & 31 & 3 & 0 & 97 \\
\hline 26 & 1 & 0 & 28 & 29 & 3,5 & 0 & 96,5 \\
\hline 31 & 0 & 0 & 27 & 27 & 0 & 0 & 100 \\
\hline 36 & 3 & 0 & 32 & 35 & 8,5 & 0 & 91,5 \\
\hline 41 & 7 & 0 & 28 & 35 & 20 & 0 & 80 \\
\hline 46 & 6 & 0 & 38 & 44 & 13.5 & 0 & 86,5 \\
\hline 51 & 16 & 0 & 26 & 42 & 38 & 0 & 62 \\
\hline 56 & 23 & 1 & 19 & 43 & 53,5 & 2,5 & 44 \\
\hline 61 & 23 & 2 & 4 & 29 & 79,5 & 7 & 13,5 \\
\hline 66 & 25 & 1 & 1 & 27 & 93 & 3,5 & 3,5 \\
\hline 71 & 32 & 3 & 0 & 35 & 91,5 & 8,5 & 0 \\
\hline$\underline{76}(\mathrm{MP})$ & 41 & 2 & 1 & 44 & $\underline{93}$ & 4,5 & 2,5 \\
\hline$\overline{81}$ & 34 & 3 & 0 & 37 & $\overline{92}$ & 8 & 0 \\
\hline 86 & 33 & 9 & 0 & 42 & 78,5 & 21,5 & 0 \\
\hline 91 & 15 & 24 & 0 & 39 & 38,5 & 61,5 & 0 \\
\hline 96 & 3 & 24 & 0 & 27 & 11 & 89 & 0 \\
\hline 101 & 3 & 36 & 0 & 39 & 7.5 & 92,5 & 0 \\
\hline 106 & 1 & 47 & 0 & 48 & 2 & 98 & 0 \\
\hline
\end{tabular}

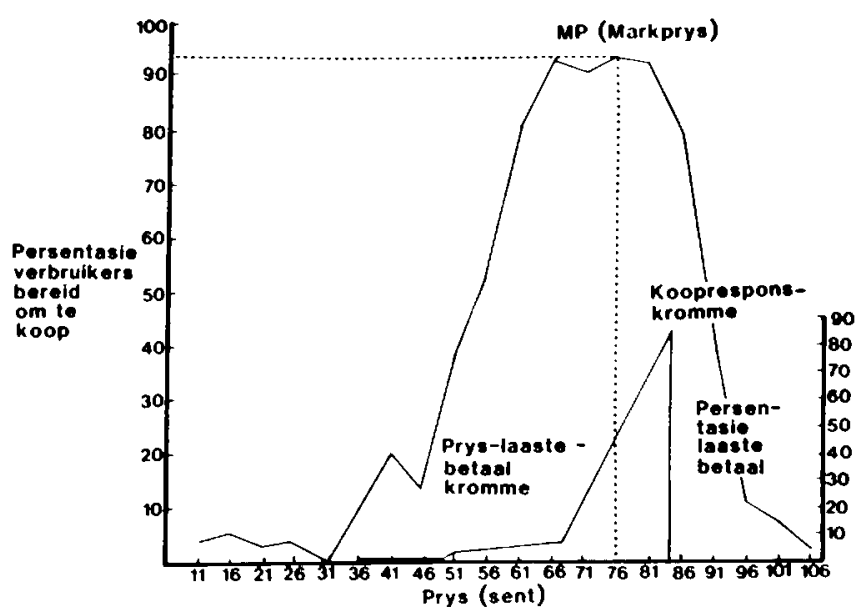

Figuur 6 Kooprespons-kromme en prys-laaste-betaal-kromme: respondente sonder bediendes 
pryse was vir $\mathbf{7 8 \%}$ en $\mathbf{9 3 \%}$ respondente onderskeidelik aanvaarbaar. Vir respondente sonder bediendes was pryse vanaf $61 \mathrm{c}$ tot by $86 \mathrm{c}$ egter vir tussen $79,5 \%$ en $\mathbf{7 8 , 5 \%}$ respondente aanvaarbaar.

Die prys-laaste-betaal-kromme toon goeie ooreenstemming met die kooprespons-kromme in die geval van respondente sonder bediendes, terwyl 'n redelike afwyking in die geval van respondente met bediendes gevind word. Die rede hiervoor is hoofsaaklik die feit dat ' $n$ groot persentasie van die markaandeel $(33,5 \%)$ nog deur die duurder handelsmerke ingeneem is. Die verbruikersweerstand teen lae: kwaliteit blyk duidelik uit die verskil in die pieke van die kooprespons en die prys-laastebetaal-krommes. Dit blyk ook duidelik dat verbruikers met bediendes laer-geprysde handelsmerke verkies terwyl verbruikers sonder bediendes 'n hoë-kwaliteit skottelgoedopwasmiddel verkies.

Die markaandeel van elke mededinger word in Tabelle 5 en 7 aangedui. Die belangrikste verskille met die totale markaandeel is die styging van die markaandele van laergeprysde handelsmerke by die respondente met bediendes terwyl die hoogste geprysde handelsmerke $86 \%$ van die mark vir skottelgoedopwasmiddels vir respondente sonder bediendes uitmaak. Die prys-kwaliteit konnotasie blyk duidelik hieruit.

\section{Respons van Sunlight Liquid-respondente}

Daar is ook besluit om die resultate van die respondente wat die markleier aangekoop het te vergelyk met die totale aantal respondente. Die resultate van die 114 respondente wat Sunlight Liquid aangekoop het, word aangetoon in Tabel 9.

Die kooprespons-krommes van die totale aantal skottelgoedopwasmiddel-respondente en dié wat Sunlight Liquid aangekoop het, word saam voorgestel in Figuur 7.

Tabel 9 Prysrespons van Sunlight Liquid-respondente

\begin{tabular}{|c|c|c|c|c|c|c|c|}
\hline \multirow[b]{2}{*}{$\begin{array}{l}\text { Pryse } \\
\text { genoem }\end{array}$} & \multirow[b]{2}{*}{$\begin{array}{c}\text { Sal } \\
\text { koop }\end{array}$} & \multirow[b]{2}{*}{$\begin{array}{c}\text { Te } \\
\text { hoog }\end{array}$} & \multirow[b]{2}{*}{$\begin{array}{c}\text { Te } \\
\text { laag }\end{array}$} & \multirow[b]{2}{*}{ Totaal } & \multicolumn{3}{|c|}{$\begin{array}{c}\text { Persentasies } \\
\text { (afgerond tot } 0,5 \text { ) }\end{array}$} \\
\hline & & & & & Koop & $\begin{array}{c}\mathrm{Te} \\
\text { hoog }\end{array}$ & $\begin{array}{c}\mathrm{Te} \\
\text { laag }\end{array}$ \\
\hline 11 & 3 & 0 & 47 & 50 & 6 & 0 & 94 \\
\hline 16 & 1 & 0 & 43 & 44 & 2 & 0 & 98 \\
\hline 21 & 2 & 0 & 30 & 32 & 6 & 0 & 94 \\
\hline 26 & 1 & 0 & 32 & 33 & 3 & 0 & 97 \\
\hline 31 & 1 & 0 & 28 & 29 & 3,5 & 0 & 96,5 \\
\hline 36 & 2 & 0 & 36 & 38 & 5 & 0 & 95 \\
\hline 41 & 4 & 0 & 28 & 32 & 12,5 & 0 & 87,5 \\
\hline 46 & 6 & 0 & 40 & 46 & 13 & 0 & 87 \\
\hline 51 & 18 & 0 & 28 & 46 & 39 & 0 & 61 \\
\hline 56 & 25 & 0 & 24 & 49 & 51 & 0 & 49 \\
\hline 61 & 26 & 0 & 5 & 31 & 84 & 0 & 16 \\
\hline 66 & 31 & 0 & 4 & 35 & 88,5 & 0 & 11,5 \\
\hline$\underline{71}(\mathrm{MP})$ & 34 & 0 & 0 & 34 & 100 & 0 & 0 \\
\hline 76 & 48 & 0 & 1 & 49 & $\overline{98}$ & 0 & 2 \\
\hline 81 & 39 & 0 & 1 & 40 & 97,5 & 0 & 2,5 \\
\hline 86 & 41 & 3 & 0 & 44 & 93 & 7 & 0 \\
\hline 91 & 16 & 30 & 0 & 46 & 35 & 65 & 0 \\
\hline 96 & 6 & 30 & 0 & 36 & 16,5 & 83,5 & 0 \\
\hline 101 & 3 & 33 & 0 & 36 & 8,5 & 91,5 & 0 \\
\hline 106 & 1 & 47 & 0 & 48 & 2 & 98 & 0 \\
\hline
\end{tabular}

Die markprys vir Sunlight Liquid-respondente is $71 \mathrm{c}$ en word dus beskou as te hoog geprys deur hierdie respondente. Dit moet egter onthou word dat 'n markprys vir alle handelsmerke beoordeel is en nie vir Sunlight Liquid afsonderlik nie, anders sou die markprys aansienlik hoër gewees het. Alle handelsmerke behalwe Sunlight Liquid en Ajax se pryse word as te laag beskou weens ' $n$ swak kwaliteitspersepsie. Vanaf 'n prys van $56 \mathrm{c}$ is die waarskynlikheid van aankope deur 'n Sunlight Liquid-respondent hoër as dié van die totale mark, terwyl onder dié prys die waarskynlikheid van aankope minder is. Dit kan ook gesien word dat eers vanaf 'n prys van $86 \mathrm{c}$ die prys as te hoog beskou word deur Sunlight Liquidaankopers terwyl $87 \%$ van die respondente reeds $46 \mathrm{c}$ as te laag beskou het.

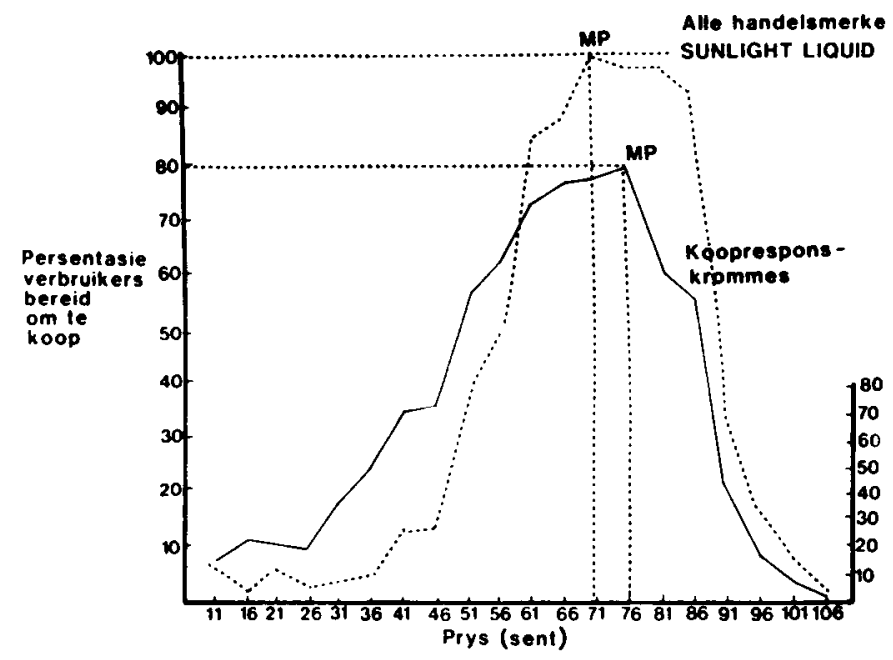

Figuur 7 Kooprespons-krommes: totale aantal respondente en aankopers van Sunlight Liquid

\section{Die implikasies en gebruik van die navorsings. resultate en die markprysbepalingsmetode}

'n Metode is ontwikkel wat in die praktyk deur bemarkers gebruik kan word vir die markprysbepaling van onduursame verbruikersgoedere. Hierdie metode sal ook gebruik kan word by die markprysbepaling van ander produkte, maar leen hom veral tot gebruik by onduursame verbruikersgoedere aangesien verbruikers baie kennis oor hierdie produkte dra en prysbewustheid hoog is by hierdie soort produkte.

In die empiriese ondersoek wat uitgevoer is, is die praktiese toepassing van hierdie metode bewys en kan die volgende belangrike inligting deur bemarkers ingewin word deur gebruikmaking van hierdie metode:

- die pryse waaronder en waarbo die verbruikers die produk as te duur of te goedkoop beskou en hoe hierdie persentasie verander soos die prys verhoog of verlaag word;

- die prysband van aanvaarbare pryse vir die verbruikers en die waarskynlikheid van aankope van 'n verbruiker teen elke prys;

- die markprys, waar die minste verbruikers die prys as te hoog of te laag beskou;

- die markaandeel van elke handelsmerk;

- is die verbruikers tevrede met die bestaande pryse of beskou hulle die produk as te hoog of te laag geprys?; 
- die effek van 'n prysverandering op verkope en markaandeel kan voor die tyd waargeneem word;

- vir nuwe produkte kan voor die tyd vasgestel word wat die potensiële verkope teen 'n gegewe prys sal wees, wat baie onnodige produkmislukkings vroegtydig sal uitskakel deur die vergelyking van die markprys en doelwitprys;

- potensiële markgeleenthede kan geidentifiseer word;

- die markpryse vir 'n produksoort en handelsmerk kan afsonderlik en gesamentlik bereken word;

- markprysbepaling kan geskied deur die vervaardiger of kleinhandelaar.

\section{Summary}

Proper pricing should be done in three phases. Firstly, the determination of the market price, namely that price which the consumers are prepared to pay for the amount of need-satisfaction they perceive from using the product. Secondly, the determination of the target price, namely that price which will give a satisfactory rate of return on investment for the firm. Thirdly, the determination of the final price, by achieving a match between the market price and the target price.

The determination of the market price is becoming more and more relevant, and up to the present time no comprehensive research has been done on this subject in South Africa. An investigation was undertaken into the present technology concerning market pricing and from this knowledge a method was developed which can be applied in the determination of the market price. These factors include the consumer as an individual, the target market, product, distribution, marketing communication and price.

The present consumer-oriented methods to determine the market price were analysed, by referring to the procedure used, the advantages, and limitations of each method. From these limitations the prerequisites for a feasible method could be derived. With this information a method to determine the market price was developed which was tested with two non-durable consumer products in an actual shop situation. The main object of this article is to give an explanation of the empirical investigation undertaken to test the feasibility of this method and the implications and conclusions derived from the results.

This method is of practical significance to marketing management. As the new method proved to give satisfactory results, the determination of the market price will enable marketing management to do consumer-oriented pricing instead of the traditional cost-oriented pricing, which will lead to better consumer satisfaction. The marketing manager can also see how the existing price is perceived by the consumers, and adjustments can be made, if necessary.

The marketing manager can now determine the range of prices that the consumers will be prepared to pay, and therefore the price limits below which quality will be under suspicion, or where the price will be too high for the perceived utility value of the product. The market share of each of the competing brands can be determined and possibilities in the existing market may be identified. The impact of a price-change on sales and market share can also be established before the actual change.

In the case of new products, market pricing will help to determine the best price for the product as perceived by the consumers by using a simulated shop situation. An additional advantage arising from this is that management can readily determine whether the desired return on investment will materialize (by comparison of the market price and the target price), which will help to reduce the unnecessary costs resulting from new product failure.

The determination and comparison of the market price and the target price will enable marketing management to determine a final price which will satisfy the needs of both the consumers and the shareholders.

\section{Verwysings}

1. Hierdie artikel is gebaseer op die outeur se M.Com.-verhandeling. LERM, C.P., Markprysbepaling by Onduursame Verbruikersgoedere. Ongepubliseerde M.Com.-verhandeling, Randse Afrikaanse Universiteit, Johannesburg, 1980.

2. LUCAS, G.H.G., DE CONING, C.. MARX, S. \& OOSTHUIZEN, H. (Reds.). Die Taak van die Bemarkingsbestuur. J.L. van Schaik (Edms.) Beperk, Pretoria, Eerste Uitgawe, 1979, p.570.

3. SHAPIRO, B.P. \& JACKSON, B.B. 'Industrial Pricing to Meet Customer Needs'. Harv. Bus. Rev., November-Desember 1978, p.49.

4. LERM, C.P. Ibid, Hfst. 3.

5. GABOR, A. \& GRANGER, C.W.J. 'Price as an Indicator of Quality, Report on an Enquiry'. Economica, Februarie 1966, p.43.

6. Onder andere deur ADAM, FOUILHE, GABOR en GRANGER \& MONROE. Sien MONROE, K.B. 'Buyers Subjective Perceptions of Price'. J. Marketing Res., Vol. X, Februarie 1973, p.75, vir 'n uiteensetting van die bevindinge.

7. GABOR, A. Pricing: Principles and Practices. Heinemann, London, 1977, p.204. 